\title{
Appendiceal Carcinoma pT2 TNM Finding v7
}

National Cancer Institute

\section{Source}

National Cancer Institute. Appendiceal Carcinoma pT2 TNM Finding v7. NCI Thesaurus. Code C89899.

Appendiceal carcinoma with tumor invading muscularis propria. (from AJCC 7th Ed.) 